\title{
PENINGKATAN KOMPETENSI MENULIS KALIMAT BERHURUF JAWA MENGGUNAKAN PASANGAN DENGAN MODEL PEMBELAJARAN KOOPERATIF TIPE MAM PADA PESERTA DIDIK KELAS VIC SD NEGERI LANDUNGSARI 01 KOTA PEKALONGAN SEMESTER I TAHUN PELAJARAN 2015/2016
}

\section{Yatini \\ SDN Landungsari 01}

\begin{abstract}
Abstrak
Rumusan masalah ini adalah bagaimana proses pelaksanaan pembelajaran, peningkatan hasil belajar dan perubahan prilaku peserta didik kelas IVC SD Negeri Landungsari 01 pada kompetensi menulis kalimat berhuruf jawa menggunakan pasangan dengan model pembelajaran kooperatif tipe MAM(Make A Match).PTK ini dilaksanakan dalam dua siklus.Terjadi perubahan perilaku ke arah lebih baik dari aspek respon peserta didik dalam menerima materi, antusias dalam pembentukan kelompok, sikap menghargai teman, keaktifan dalam membantu teman, kemampuan berkominikasi dengan teman, keseriusan mengerjakan kuis dan ketepatan dalam mengerjakan tugas. Rata-rata hasil belajar yang dicapai peserta didik pada prasiklus sebesar 55,16 dan berada dalam kategori cukup. Pada siklus I, nilai rata-rata peserta didik mengalami peningkatan sebesar 13,68 atau sebesar $43 \%$ menjadi sebesar 68,84 dan berada dalam kategori baik. Pada siklus II, nilai rata-rata peserta didik mengalami peningkatan sebesar 9,96 atau sebesar $31 \%$ menjadi sebesar 78,80 dan berada dalam kategori baik. Peningkatan nilai rata-rata tersebut membuktikan keberhasilan pembelajaran menulis kalimat berhuruf jawa menggunakan pasangan dengan model pembelajaran kooperatif tipe MAM (Make A Match)
\end{abstract}

Kata Kunci: kompetensi menulis kalimat berhuruf jawa menggunakan pasangan, model pembelajaran kooperatif tipe MAM (Make A Match) 


\section{PENDAHULUAN}

Pembelajaran Bahasa Jawa tentang menulis kalimat berhuruf jawa, penting untuk melestarikan budaya jawa sebagai salah satu unsur kebudayaan Nasional. Namun demikian kenyataan pembelajaran Bahasa Jawa menulis kalimat berhuruf jawa menggunakan pasangan pada peserta didik Kelas VIC SD Negeri Landungsari 01 Kota Pekalongan semester I tahun pelajaran 2015/2016 hasilnya masih rendah. Kelas VIC dengan jumlah peserta didik 32 orang, pada pembelajaran kompetensi "Menuliskalimat berhuruf jawamenggunakan pasangan" hasilnya 23 peserta didik (72\%) belum tuntas, dan baru 9 peserta didik atau 28,125\%yang mencapai ketuntasan, melampaui Kriteria Ketuntasan Minimal (KKM) yang ditetapkan di Kelas VIC SD Negeri Landungsari 01 Kota Pekalongan yaitu 61.

Model pembelajaran make and match adalah sistem pembelajaran yang mengutamakan penanaman kemampuan sosial terutama kemampuan bekerja sama, kemampuan berinteraksi disamping kemampuan berpikir cepat melalui permainan mencari pasangan dengan dibantu kartu (Wahab, 2007 : 59). Menurut Rusman (2011: 223-233) Model Make-A Match (membuat pasangan) merupakan salah satu jenis dari metode dalam pembelajaran kooperatif. Model make-a match atau mencari pasangan merupakan salah satu alternatif yang dapat diterapkan kepada siswa. Kelebihan model pembelajaran tipe Make-A Match antara lain: (a) dapat meningkatkan aktivitas belajar siswa, baik secara kognitif maupun fisik; (b) karena ada unsur permainan, metode ini menyenangkan,(c) meningkatkan pemahaman siswa terhadap materi yang dipelajari dan dapat meningkatkan motivasi belajar siswa.

Dengan kelebihan model pembelajaran kooperatif tipe MAM (Make A Match), maka cocok digunakan dalam pembelajaran Bahasa Jawa dalam peningkatan kompetensi menulis kalimat berhuruf jawa menggunakan pasangan.
Kompetensi menulis kalimat berhuruf jawa menggunakan pasangan pada peserta didik kelas VIC SD Negeri Landungsari 01 Kota Pekalongan masih rendah, disebabkan bagi peserta didik pelajaran Bahasa Jawa menulis huruf jawa cukup sulit untuk dipelajari, peserta didik juga kurang aktif dalam kegiatan pembelajaran, peserta didik cenderung tidak peduli ketika guru menulis huruf jawa di papan tulis. Keadaan peserta didik di atas dipengaruhi oleh guru masih menggunakan pendekatan pembelajaran yang konvensional. Guru dalam melakukan pembelajaran masih menggunakan hafalan aksara jawa kepada peserta didik sehingga pembelajaran menjadi kurang menarik. Guru belum optimal dalam menggunakan media. Pembelajaran masih berpusat pada guru (teacher center) sehingga belajar peserta didik kurang bermakna. Lingkungan peserta didik kurang mendukung dalam berbahasa Jawa karena dalam pergaulan sehari-hari sering menggunakan Bahasa Indonesia.

Karena hal tersebut, dalam pembelajaran Bahasa Jawa, peserta didik kelas VI C SD Negeri Landungsari 01 Kota Pekalongan mengalami kesulitan dalammenuliskalimat berhuruf jawamenggunakan pasangan.Oleh sebab itu penulis berusaha untuk memperbaiki pembelajaran di kelas VIC SD Negeri Landungsari 01 Kota Pekalongan untuk meningkatkan kompetensi peserta didik tentangmenuliskalimat berhuruf jawamenggunakan pasangan, melalui Penelitian Tindaka Kelas (PTK) yang pelaksanaannya di rencanakan dua siklus.Diharapkan setelah guru mengubah strategi pembelajaran dengan model pembelajaran kooperatif tipe MAM (MakeA Match) dan pembelajaran yang kontekstual, anak lebih tertarik dan merasa senang, dapat meningkatkan kompetensi menuliskalimat berhuruf jawamenggunakan pasangan, dan mencapai Kriteria Ketuntasan Minimal yang telah ditetapkan SD Negeri Landungsari 01 Kota Pekalongan.

Rumusan masalah dalam penelitian ini adalah sebagai berikut : 1) Bagaimanakah proses pembelajaran 
kompetensi menuliskalimat berhuruf jawa menggunakan pasangan pada peserta didik kelas VIC SD Negeri Landungsari 01 Kota Pekalongan ?; 2) Seberapa besar hasil peningkatan yang diperoleh peserta didik dalam pembelajaran kompetensi menuliskalimat berhuruf jawa menggunakan pasanganpada peserta didik kelas VIC SD Negeri Landungsari 01 Kota Pekalongan ?; dan 3) Bagaimanakah perubahan sikap dan tingkah laku setelah mendapatkan pembelajaran kompetensi menuliskalimat berhuruf jawa menggunakan pasanganpada peserta didik kelas VIC SD Negeri Landungsari 01 Kota Pekalongan?

Tujuan penelitian ini adalah untuk: 1) Mendiskripsikan proses pelaksanaan pembelajaran kompetensi menuliskalimat berhuruf jawa menggunakan pasangandengan model pembelajaran kooperatif tipe MAM (Make-A Match) pada peserta didik kelas VIC SD Negeri Landungsari 01 Kota Pekalongan; 2) Mendiskripsikan peningkatan pembelajaran kompetensi menuliskalimat berhuruf jawa menggunakan pasangandengan model pembelajaran kooperatif tipe MAM (Make-A Match) pada peserta didik kelas VIC SD Negeri Landungsari 01 Kota Pekalongan; 3) Mendiskripsikan perubahan tingkah laku pada peserta didik setelah mengikuti pembelajaran menulis kalimat berhuruf jawa menggunakan pasangan dengan model pembelajaran kooperatif tipe MAM (Make-A Match) pada peserta didik kelas VIC SD Negeri Landungsari 01 Kota Pekalongan.

Penelitian ini diharapkan dapat dimanfaatkan sebagai panduan guru dalam pembelajaran Bahasa Jawa pada materi menulis huruf jawa di sekolah dasar denganmemanfaatkan model pembelajaran kooperatif tipe MAM (Make-A $M a t c h)$,dapat menumbuhkan minat belajar, dapat meningkatkan kompetensipeserta didik untuk meningkatkan hasil belajar siswa melalui pembelajaran dengan memanfaatkan langkah-langkah model pembelajaran kooperatif tipe MAM (MakeA Match).

\section{LANDASAN TEORITIS DAN HIPOTESIS \\ Pembelajaran Bahasa Jawa}

Bahasa Jawa adalah suatu bahasa daerah yang merupakan bagian dari kebudayaan nasional Indonesia, yang hidup dan tetap dipergunakan dalam masyarakat bahasa yang bersangkutan. Bahasa Jawa terus berkembang maka diperlukan penyesuaian ejaan huruf Jawa. Bahasa Jawa merupakan salah satu bahasa daerah sehingga perlu dilestarikan supaya tidak hilang keberadaannya.Menurut Kurikulum Tingkat Satuan Pendidikan (KTSP) (2006) ruang lingkup mata pelajaran bahasa Jawa adalah: (a) kemampuan berkomunikasi yang meliputi mendengarkan, berbicara, membaca, dan menulis; (b) kemampuan menulis huruf Jawa; (c) meningkatkan kepekaan dan penghayatan terhadap karya sastra Jawa; (d) memupuk tanggung jawab untuk melestarikan hasil kreasi budaya sebagai salah satu unsur kebudayaan nasional.

Pembelajaran bahasa Jawa di sekolah dasar meliputi membaca, menyimak, berbicara, menulis. Membaca diarahkan pada kemampuan memahami isi bacaan, makna suatu bacaan ditentukan oleh situasi dan konteks dalam bacaan. Kegiatan menyimak pada hakikatnya sama dengan kegiatan membaca hanya saja pada menyimak merupakan pemahaman teks lisan. Kegiatan menulis diarahkan untuk mengembangkan kemampuan mengungkapkan gagasan, pendapat, pesan dan perasaan secara tertulis. Kegiatan berbicara diarahkan pada kemampuan mengungkapkan gagasan, pendapat, pesan dan perasaan secara lisan dengan menggunakan bahasa Jawa. Berdasarkan uraian tentang bahasa Jawa di atas melandasi penetapan tujuan pembelajaran dikelas. Tujuan pembelajaran bahasa Jawa khususnya keterampilan menulis kelas VI, tertuang dalam silabus mata pelajaran muatan lokal (bahasa Jawa) untuk jenjang 
pendidikan sekolah dasar negeri maupun swasta yang memuat standar kompetensi dan kompetensi dasar terutama untuk kelas VI Semester I.

Tabel 1. Silabus Bahasa Jawa kelas VI SD Semester I

\begin{tabular}{|c|c|}
\hline Standar Kompetensi & Kompetensi Dasar \\
\hline $\begin{array}{l}\text { 1. Mendengarkan } \\
\text { Mampu mendengarkan dan memahami } \\
\text { ragam wacana lisan melalui pembacaaan } \\
\text { teks cerita anak dan cerita wayang. }\end{array}$ & $\begin{array}{l}\text { 1.1 Mendengarkan cerita anak } \\
\text { 1.2 Mendengarkan cerita tokoh } \\
\text { wayang Arjuna }\end{array}$ \\
\hline $\begin{array}{l}\text { 2. } \\
\text { Berbicara } \\
\text { Mampu mengungkapan pendapat dan } \\
\text { perasaan secara lisan tentang hasil } \\
\text { pengamatan dengan ragam bahasa } \\
\text { tertentu. } \\
\end{array}$ & $\begin{array}{l}\text { 2.1 Melaporkan hasil pengamatan } \\
\text { 2.2 Menanggapi hasil pengamatan }\end{array}$ \\
\hline $\begin{array}{l}\text { 3. } \\
\text { Membaca } \\
\text { nompu membaca dan memahami teks } \\
\text { mengapresiasikan tembang macapat. }\end{array}$ & $\begin{array}{l}\text { 3.1 Membaca pemahaman teks non } \\
\text { sastra } \\
\text { 3.2 Membaca kalimat berhuruf jawa } \\
\text { yang menggunakan pasangan. } \\
\text { 3.3 Membaca tembang Pangkur. }\end{array}$ \\
\hline $\begin{array}{l}\text { 4. Menulis } \\
\text { Mampu menulis karangan dalam ragam } \\
\text { bahasa tertentu dan menulis huruf Jawa }\end{array}$ & $\begin{array}{l}\text { 4.1 Menulis karangan } \\
\text { 4.2 Menulis kalimat berhuruf jawa } \\
\text { menggunakan pasangan. }\end{array}$ \\
\hline
\end{tabular}

Standar kompetensi menulis yang akan diteliti, yaitu standar kompetensi mampu menulis karangan dalam ragam bahasa tertentu dan menulis huruf Jawa. Dan kompetensi dasarnya adalah menulis kalimat berhuruf jawa menggunakan pasangan.

\section{Hakikat menulis}

Menurut Tarigan dalam Syarif, Zulkarnaini, Sumarno (2009: 5) menulis berarti mengekpresikan secara tertulis gagasan, ide, pendapat, atau pikiran dan perasaan. Lado dalam Elina Syarif, Zulkarnaini, Sumarno (2009: 5) juga mengungkapkan pendapatnya mengenai menulis yaitu: meletakkan simbol grafis yang mewakili bahasa yang dimengerti orang lain.Nurjamal dalam Sumirat, Darwis (2011:69) mengemukakan bahwa menulis sebagai sebuah keterampilan berbahasa adalah kemampuan seseorang dalam mengemukakan gagasan, perasaan, dan pemikiran-pemikirannya kepada orang atau pihak lain dengan menggunakan media tulisan.

Berdasarkan pendapat para ahli mengenai menulis, peneliti sependapat dalam penelitian ini bahwa menulis yaitu meletakkan simbol grafis yang mewakili bahasa yang dimengerti orang lain. Karena menulis dengan huruf Jawa (aksara jawa) menggunakan simbol khusus untuk bisa dipahami orang lain.

\section{Huruf Jawa (Aksara jawa )}

Dalam pembelajaran Bahasa Jawa, huruf Jawa lebih dikenal dengan nama aksara jawa. Aksara jawa ada dua macam yaitu aksara jawa nglegena/carakan (belum mendapat tambahan) dan aksara jawa pasangan yaitu : 
Tabel 2 Aksara jawa

\begin{tabular}{|c|c|c|c|c|}
\hline $\mathrm{a}$ & $\mathrm{n}$ & $\mathrm{c}$ & $\mathrm{r}$ & $\mathrm{k}$ \\
$\mathrm{ha}$ & $\mathrm{na}$ & $\mathrm{ca}$ & $\mathrm{ra}$ & $\mathrm{ka}$ \\
\hline $\mathrm{f}$ & $\mathrm{t}$ & $\mathrm{s}$ & $\mathrm{w}$ & $\mathrm{I}$ \\
$\mathrm{da}$ & $\mathrm{ta}$ & $\mathrm{sa}$ & wa & la \\
\hline $\mathrm{p}$ & $\mathrm{d}$ & $\mathrm{j}$ & $\mathrm{y}$ & $\mathrm{v}$ \\
$\mathrm{pa}$ & $\mathrm{dha}$ & $\mathrm{ja}$ & $\mathrm{ya}$ & nya \\
\hline $\mathrm{m}$ & $\mathrm{g}$ & $\mathrm{b}$ & $\mathrm{q}$ & $\mathrm{z}$ \\
$\mathrm{ma}$ & $\mathrm{ga}$ & $\mathrm{ba}$ & tha & nga \\
\hline
\end{tabular}

Aksara pasangan ialah huruf Jawa seperti halnya carakan, yang jumlahnya juga 20 buah, tetapi bentuk dan fungsinya berbeda. Penulisan huruf pasangan ada yang di depan huruf carakan dan ada yang dibelakang huruf carakan. Fungsi huruf pasangan adalah untuk menghilangkan tanda pangkon dan untuk mematikan huruf di depan atau di atasnya. Pasangan dapat diartikan sebagai "setelan", karena setiap huruf jawa mempunyai pasangan sendirisendiri seperti di bawah ini:

Tabel 3 Aksara Pasangan

\begin{tabular}{|c|c|c|c|c|}
\hline $\mathrm{Ah}$ & $\mathrm{nN}$ & $\mathrm{CC}$ & $\mathrm{rR}$ & $\mathrm{kK}$ \\
\hline $\mathrm{Ff}$ & $\mathrm{tT}$ & $\mathrm{sS}$ & $\mathrm{wW}$ & $\mathrm{lL}$ \\
\hline $\mathrm{pP}$ & $\mathrm{dD}$ & $\mathrm{jJ}$ & $\mathrm{yY}$ & $\mathrm{VV}$ \\
\hline $\mathrm{Mm}$ & $\mathrm{gG}$ & $\mathrm{bB}$ & $\mathrm{qQ}$ & $\mathrm{zZ}$ \\
\hline
\end{tabular}

Aksara jawa hingga sekarang masih digunakan di dalam pembelajaran bahasa Jawa di sekolah. Aksara jawa terintegrasi pada mata pelajaran bahasa Jawa.

\section{Model Pembelajaran tipe MAM (Make- A Match)}

Model pembelajaran menurut Joyce \& Weiladalah suatu rencana atau pola yang dapat digunakan untuk membentuk kurikulum (rencana pembelajaran jangka panjang), merancang bahan-bahan pembelajara, dan membimbing pembelajaran dikelas atau yang lain (Joyce \& Weil, 1980:1). Sedangkan model Make-A Match merupakan model pembelajaran aktif, kreatif, efektif, dan menyenangkan (PAKEM), yaitu pembelajaran kooperatif (Cooperatif Learning) yang mengutamakan kerja sama dan kecepatan di antara peserta didik untuk mencapai tujuan pembelajaran.

Dalam model pembelajaran kooperatif terdapat enam langkah utama atau tahapan di dalam pelajaran, pelajaran dimulai dengan guru menyampaikan tujuan pelajaran dan memotivasi peserta didik belajar. Fase ini diikuti oleh penyajian informasi, seringkali dengan bahan bacaan daripada secara verbal. Selanjutnya peserta didik dikelompokkan ke dalam kelompok belajar. Tahap ini diikuti bimbingan guru pada saat peserta didik bekerja bersama untuk menyelesaikan tugas bersama mereka. Fase terakhir pembelajaran kooperatif meliputi presentasi hasil akhir kerja kelompok, atau evaluasi tentang apa yang telah mereka pelajari dan memberi penghargaan terhadap usaha-usaha kelompok maupun individu. (Ahmadi, 2010)model pembelajaran ini memiliki ciriciri yaitu untuk menuntaskan materi belajarnya, peserta didik belajar dalam kelompok atau bersama peserta didik lain.

Model pembelajaran make and match adalah sistem pembelajaran yang mengutamakan penanaman kemampuan sosial terutama kemampuan bekerja sama, kemampuan berinteraksi disamping kemampuan berpikir cepat melalui permainan mencari pasangan dengan dibantu kartu (Wahab, 2007 : 59). 
Suyatno (2009 : $\quad 72)$

mengungkapkan bahwa model make and match adalah model pembelajaran dimana guru menyiapkan kartu yang berisi soal atau permasalahan dan menyiapkan kartu jawaban kemudian peserta didik mencari pasangan kartunya. Model pembelajaran make and match merupakan bagian dari pembelajaran kooperatif. Model pembelajaran kooperatif didasarkan atas falsafah homo homini socius, falsafah ini menekankan bahwa manusia adalah mahluk sosial (Lie, 2003:27). Model make and match melatih peserta didik untuk memiliki sikap sosial yang baik dan melatih kemampuan peserta didik dalam bekerja sama disamping melatih kecepatan berfikir peserta didik.

Model MAM (Make-A Match)atau mencari pasangan merupakan salah satu alternatif yang dapat diterapkan kepada peserta didik. Penerapan metode ini dimulai dari teknik yaitu peserta didik disuruh mencari pasangan kartu yang merupakan jawaban/soal sebelum batas waktunya, peserta didik yang dapat mencocokkan kartunya diberi point.

Adapun kelebihan pembelajaran kooperatif tipe MAM (Make-A Match) yaitu:

1. Suasana kegembiraan akan tumbuh dalam proses pembelajaran (Let them move).

2. Kerjasama antara sesama peserta didik terwujud secara dinamis.

3. Munculnya dinamika gotong royong yang merata diseluruh peserta didik

4. Murid mencari pasangan sambil belajar mengenai suatu konsep atau topic dalam suasana menyenangkan.

Selain memiliki kelebihan dalam pembelajaran ini, juga terdapat kelemahan dalam penerapan yaitu:

1. Diperlukan bimbingan dari guru untuk melakukan kegiatan.

2. Waktu yang tersedia perlu dibatasi jagan sampai peserta didik terlalu banyak bermain-main dalam proses pembelajaran.
3. Guru perlu persiapan alat dan bahan yang memadai.

4. Jika kelas termasuk gelas gemuk (lebih dari 30 orang/kelas) berhati-hatilah.

5. Memakan waktu yang banyak karena sebelum masuk kelas terlebih dahulu kita mempersiapkan kartu-kartu.

Dengan diketahui kelemahan model pembeajaran tipe MAM (Make-A Match)ini diharapkan akan dapat diminimalisir keberadaannya dalam pembelajaran yang akan disajikan.

\section{Kerangka Berfikir}

Model pembelajaran kooperatif tipe MAM (Make-A Match) adalah satu pilihan tepat yang mampu menjembatani guru dan peserta didik untuk melewati proses pembelajaran yang bermakna baik bagi peserta didik maupun bagi guru. Pembelajaran model koooperatif tipe MAM (Make-A Match)adalah salah satu pembelajaran kooperatif yang diterapkan untuk peserta didik mencari pasangan sambil belajar mengenai suatu konsep atau topik dalam suasana yang menyenangkan. Sebagaimana model yang lain, model ini merupakan model pembelajaran berkelompok (learning community). Model ini dapat membangkitkan semangat peserta didik dengan mengikutsertakan peserta didik untuk aktif dalam proses pembelajaran.

Model MAM (Make-A Match) melatih peserta didik untuk memiliki sikap sosial yang baik dan melatih kemampuan peserta didik dalam bekerja sama disamping melatih kecepatan berfikir peserta didik. Model ini sangat sederhana tetapi di dalamnya peserta didik diberi kesempatan untuk melakukan kolaborasi dan elaborasi dengan teman sebaya dalam bentuk diskusi kelompok untuk memecahkan suatu permasalahan". Tujuan utamanya adalah agar peserta didik lebih termotivasi terhadap pembelajaran, dapat bekerjasama dengan teman dan pada akhirnya kompetensinya akan meningkat secara signifikan.

\section{Hipotesis Tindakan}


Berdasarkan kerangka berpikir tersebut, peneliti berasumsi bahwa: 1) Ada peningkatan proses dalam pembelajaran menulis kalimat berhuruf jawa menggunakan pasangan peserta didik setelah dilakukan pembelajaran dengan model pembelajaran kooperatif tipe MAM (Make-A Match); 2) Ada peningkatan kompetensi dalam pembelajaran menulis kalimat berhuruf jawa menggunakan pasangan peserta didik setelah dilakukan pembelajaran dengan model pembelajaran kooperatif tipe MAM (Make-A Match); 3)Ada perubahan perilaku dalam pembelajaran menulis kalimat berhuruf jawa menggunakan pasangan peserta didik setelah dilakukan pembelajaran dengan model pembelajaran kooperatif tipe MAM (Make-A Match).

\section{METODE PENELITIAN}

Penelitian ini adalah penelitian tindakan kelas (PTK). Penelitian tindakan kelas adalah penelitian yang berbasis kelas, oleh karena itu masalah yang diteliti dalam PTK adalah masalah yang muncul dalam kelas. Dalam penelitian ini akan dilakukan dua siklus. Siklus I akan digunakan untuk mengetahui kemampuan peserta didik dalam menulis kalimat berhuruf jawa menggunakan pasangan dalam tindakan awal penelitian dan sekaligus digunakan sebagai refleksi untuk melakukan siklus II, sedangkan siklus II bertujuan untuk mengetahui peningkatan perbaikan terhadap pelaksanaan proses belajar mengajar yang didasarkan pada refleksi siklus I. Penelitian ini dilaksanakan dalam bentuk proses pengkajian berdaur. Proses pengkajian terdiri atas empat tahap, yaitu: perencanaan, tindakan, observasi, dan refleksi. Observasi awal dilakukan sebelum melaksanakan keempat tahap tersebut supaya peneliti dapat mengetahui kondisi peserta didik selama melaksanakan pembelajaran di kelas untuk mengidentifikasi kesulitan-kesulitan peserta didik dalam pembelajaran. Selain itu, peneliti dan peserta didik bisa saling mengenal sehingga penelitian yang akan dilakukan dapat berlangsung dengan lancar. Sebelum penelitian tindakan siklus I dilaksanakan, peneliti melakukan tes awal untuk mengetahui seberapa jauh kemampuan peserta didik menulis kalimat berhuruf jawa menggunakan pasangan menghargai. Hasil tes awal dijadikan pedoman untuk perbaikan pada siklus I dan siklus II.

Subyek penelitian tindakan kelas iniadalah kemampuan peserta didik dalam pembelajaran menulis kalimat berhuruf jawa menggunakan pasangan. Dalam penelitian ini, data yang diperoleh dari peserta didik kelas VIC SD Negeri Landungsari 01 Kota Pekalongan. Peneliti mengambil subyek tersebut denganalasan yaitu: (1) berdasarkan hasil wawancara yang dilakukan dengan guru kelas VIC, tentang kondisi peserta didik terhadap pencapaian kemampuan pembelajaran Bahasa Jawa khususnya menulis kalimat berhuruf jawa menggunakan pasangan, (2) sesuai dengan kurikulum standar isi yang menyatakan bahwa kelas VIC harus dapat menulis kalimat berhuruf jawa menggunakan pasangan dan (3) pada kelas VIC adalah kelas dengan penerapan pembelajaran dengan kurikulum tingkat satuan pendidikan.

Penelitian ini menggunakan dua variabel, yaitu kemampuan peserta didik dalam pembelajaranmenulis kalimat berhuruf jawa menggunakan pasangan dan variabel penggunaan model pembelajaran kooperatif tipe MAM (Make-A Match).Indikator kinerja dalam penelitian ini meliputi dua aspek, yaitu aspek kuantitatif dan aspek kualitatif.Dalam indikator kuantitatif, penilaian dilakukan atas dasar teknik tes. Peserta didik dinyatakan berhasil melakukan pembelajaran menulis kalimat berhuruf jawa menggunakan pasangan jika nilai yang diperoleh sesuai dengan target yang diharapkan. Dalam penelitian ini menghendaki nilai yang dicapai sesuai dengan KKM, yaitu sebesar 61. Peserta didik yang memperoleh nilai minimal 61 maka dinyatakan tuntas, 
sementara peserta didik yang memperoleh nilai di bawah 61 dinyatakan belum tuntas. Sedangkan dalam indikator kualitatif penilaian dilakukan atas dasar teknik nontes. Indikator kualitatif untuk pembelajaran menulis kalimat berhuruf jawa menggunakan pasangan dengan model pembelajaran kooperatif tipe MAM (Make-A Match) yaitu mengenai proses pembelajaran dan perubahan perilakun peserta didik setelah dilakukan pembelajaran menulis kalimat berhuruf jawa menggunakan pasangan dengan model pembelajaran kooperatif tipe MAM (Make-A Match)

Instrumen penelitian yang digunakan untuk pengumpulan data dalam penelitian tindakan kelas ini berupa instrumen tes dan instrumen nontes. Instrumen tes digunakan untuk mengetahui data kemampuan peserta didik dalam pembelajaran menulis kalimat berhuruf jawa menggunakan pasangan . Instrumen nontes, yaitu lembar observasi, lembar jurnal, lembar wawancara, dan lembar dokumentasi foto digunakan untuk mengungkapkan perubahan tingkah laku peserta didik selama mengikuti pembelajaran menulis kalimat berhuruf jawa menggunakan pasangan dengan model pembelajaran kooperatif tipe MAM (Make-A Match).

Teknik pengumpulan data adalah cara yang digunakan untuk mengumpulkan data penelitian. Dalam penelitian ini, teknik yang digunakan adalah teknik tes dan nontes. Data tes dikumpulkan melalui penilaian tes kemampuan menulis kalimat berhuruf jawa menggunakan pasangan dengan model pembelajaran kooperatif tipe MAM (Make-A Match), sedangkan data nontes dikumpulkan melalui observasi, catatan lapangan, catatan harian, wawancara, dan dokumentasi.

\section{HASIL PENELITIAN DAN PEMBAHASAN \\ Pra Siklus}

Hasil tes awal kemampuan peserta didik dalam menulis kalimat berhuruf jawa menggunakan pasangan yang indikatornya meliputi : (1) mampu menentukan pasangan huruf jawa dalam kalimat. 2) mampu menulis kalimat berhuruf jawa menggunakan pasangan (3) mampu menyalin kalimat tulisan huruf jawa dengan tulisan huruf latin.Menunjukan bahwa kemampuan menulis kalimat berhuruf Jawa menggunakan pasangan peserta didik kelas VIC SD Negeri Landungsari 01 Kota Pekalongan pada tahap prasiklus masih dalam kategori cukup, terbukti dengan nilai rata-rata kelas yang dicapai sebesar 55,16dalam rentang nilai 51-60. Berdasarkan data yang diperoleh, tidak ada peserta didik yang mendapatkan nilai dengan kateori sangat baik. Terdapat 9peserta didik atau sebesar $28 \%$ yang mendapatkan nilai dengan kategori baik dengan rentang nilai 61-84. Adapun kategori cukup sebanyak 11 peserta didik atau sebesar 34\% dengan rentang nilai 5160 dan kategori kurang sebanyak 12 peserta didik atau sebesar 38\% dengan rentang nilai $0-50$. Sebagian besar peserta didik masih memperoleh skor berkategori cukup dan kurang. Jadi, perlu segera dilakukan perbaikan, agar kemampuan dalam menulis kalimat berhuruf Jawa menggunakan pasangan peserta didik meningkat.

Sedangkan hasil tes kemampuan dalam menulis kalimat berhuruf Jawa menggunakan pasangan untuk setiap indikator pada prasiklus. Menunjukan bahwa kemampuan menentukan pasangan huruf jawa dalam kalimat, peserta didik kelas VIC SD Negeri Landungsari 01 Kota Pekalongan pada tahap prasiklus masih dalam kategori cukup,terbukti dengan nilai rata-rata kelas yang dicapai sebesar 59,38dalam rentang nilai 51-60. Berdasarkan data dari tersebut, tidak ada peserta didik yang mendapatkan nilai dengan kateori sangat baik. Terdapat 9 peserta didik atau sebesar $28 \%$ yang mendapatkan nilai dengan kategori baik dengan jumlah skor 650. Adapun kategori cukup sebanyak 12 peserta didik atau 
sebesar 38\% dengan rentang nilai 51-60 dan kategori kurang sebanyak 11 peserta didik atau sebesar 34\% dengan rentang nilai 0-50. Sebagian besar peserta didik masih memperoleh skor berkategori cukup dan kurang. Kemudian untuk kemampuan menulis kalimat berhuruf jawa menggunakan pasangan peserta didik kelas VIC SD Negeri Landungsari 01 Kota Pekalongan pada tahap prasiklus masih dalam kategori kurang, terbukti dengan nilai rata-rata kelas yang dicapai sebesar 50,94 dalam rentang nilai 0-50. Berdasarkan data yang diperoleh, tidak ada peserta didik yang mendapatkan nilai dengan kateori sangat baik. Terdapat 5 peserta didik atau sebesar $16 \%$ yang mendapatkan nilai dengan kategori baik dengan jumlah skor 360. Adapun kategori cukup sebanyak 6 peserta didik atau sebesar 19\% dengan rentang nilai 51-60 dan kategori kurang sebanyak 21 peserta didik atau sebesar 54\% dengan rentang nilai 0-50. Sebagian besar peserta didik masih memperoleh skor berkategori kurang. Selanjutnya, untuk indikator menyalin kalimat tulisan huruf jawa dengan tulisan huruf latin kategori baik sebanyak 6 peserta didik atau sebesar 19\%, kategori cukup sebanyak 8 peserta didik atau sebesar $25 \%$, sedangkan kategori kurang sebanyak 18 peserta didik atau sebesar 56\%. Dengan demikian peserta didik yang berhasil mencapai ketuntasan pada indikator ini sebanyak 6 peserta didik atau sebesar $19 \%$. Jadi, nilai rata-rata kemampuan menulis kalimat berhuruf jawa menggunakan pasangan indikator mampu menyalin kalimat tulisan huruf jawa dengan tulisan huruf latin pada prasiklus sebesar 54,69 atau kategori cukup. Sebagian besar peserta didik masih memperoleh skor berkategori cukup dan kurang.

\section{Hasil Siklus 1}

Proses Pembelajaran Menulis Kalimat Berhuruf Jawa Menggunakan Pasangan dengan Model Pembelajaran Kooperatif Tipe MAM pada Siklus I

Proses pembelajaran menulis kalimat berhuruf jawa menggunakan pasangan dengan model pembelajaran kooperatif tipe MAM (Make A Match) sebagai berikut:

Tabel 4. Proses Pembelajaran

\begin{tabular}{|c|l|c|c|}
\hline No & \multicolumn{1}{|c|}{ Indikator } & F & $\begin{array}{c}\text { Prosent } \\
\text { ase }\end{array}$ \\
\hline 1 & $\begin{array}{l}\text { Intensifnya proses internalisasi penumbuhan minat pad } \\
\text { pembelajaran menulis kalimat berhuruf jaw } \\
\text { menggunakan pasangan }\end{array}$ & 23 & $72 \%$ \\
\hline 2 & $\begin{array}{l}\text { Terjadinya proses penjelasan yang kondusif tentang } \\
\text { cara menulis kalimat berhuruf Jawa menggunakan } \\
\text { pasangan.. }\end{array}$ & 21 & $67 \%$ \\
\hline 3 & $\begin{array}{l}\text { Intensifnya proses peserta didik berdiskusi dengan } \\
\text { didampingi guru sehingga peserta didik mampu } \\
\text { berperilaku melestarikan budaya Jawa. }\end{array}$ & 22 & $69 \%$ \\
\hline 4 & $\begin{array}{l}\text { Kondusifnya kondisi peserta didik saat memaparkan } \\
\text { hasil diskusi di depan kelas }\end{array}$ & 21 & $67 \%$ \\
\hline 5 & $\begin{array}{l}\text { Terbangunnya suasana yang reflektif sehingga peserta } \\
\text { didik bisa menyadari kekurangan saat proses } \\
\text { pembelajaran dan mengetahui apa yang akan } \\
\text { dilakukan setelah proses pembelajaran. }\end{array}$ & 20 & $63 \%$ \\
\hline
\end{tabular}

Keterangan :

Sangat baik 


$\begin{array}{ll}\text { Baik } & : 61 \%-84 \% \\ \text { Cukup } & : 51 \%-60 \% \\ \text { Kurang } & : 0 \%-50 \%\end{array}$

Dari Tabel 4 di atas ditunjukkan indikator intensifnya proses internalisasi penumbuhan minat belajar Bahasa Jawa, terdapat 23 peserta didik yang memperhatikan atau sebesar $72 \%$ dan termasuk dalam kategori baik. Indikator terjadinya proses penjelasan yang kondusif tentang bagaimana cara menulis kalimat berhuruf Jawa menggunakan pasangan., terdapat 21 peserta didik yang memperhatikan atau sebesar $67 \%$ dan termasuk dalam kategori baik. Indikator intensifnya proses peserta didik berdiskusi dengan didampingi guru sehingga peserta didik mampu berperilaku melestarikan budaya Jawa, terdapat 22 peserta didik yang memperhatikan atau sebesar 69\% dan termasuk dalam kategori baik. Indikator kondusifnya kondisi peserta didik saat memaparkan hasil diskusi di depan kelas, terdapat 21 peserta didik yang memperhatikan atau sebesar $67 \%$ dan termasuk dalam kategori baik. Indikator terbangunnya suasana yang reflektif sehingga peserta didik bisa menyadari kekurangan saat proses pembelajaran dan mengetahui apa yang akan dilakukan setelah proses pembelajaran, terdapat 20 peserta didik yang memperhatikan atau sebesar $63 \%$ data termasukdalam kategori baik.

\section{Peningkatan Kemampuan Menulis Kalimat Berhuruf Jawa Menggunakan Pasangandengan Model Pembelajaran Kooperatif Tipe MAM}

Berdasarkan hasil tes pada siklus I, telah terjadi peningkatan kemampuan menulis kalimat berhuruf jawa menggunakan pasanganpeserta didik kelas VIC SD Negeri Landungsari 01 Kota Pekalongan. Peningkatan ini dipengaruhi oleh penggunaan model pembelajaran kooperatif tipe MAM (Make A Match) dalam pembelajaran. Berikut hasil tes siklus I kemampuan peserta didik dalam menulis kalimat berhuruf jawa menggunakan pasangan dapat dilihat pada tabel di bawah ini.

Tabel 5. Hasil Tes Awal Kemampuan Menulis Kalimat Berhuruf Jawa Menggunakan Pasangan Siklus I

\begin{tabular}{|c|c|c|c|c|c|c|}
\hline No & Kategori & $\begin{array}{c}\text { Rentang } \\
\text { Nilai }\end{array}$ & $\mathbf{F}$ & Bobot & $\begin{array}{c}\text { Presenta } \\
\text { se }(\%)\end{array}$ & Rata-rata \\
\hline 1 & $\begin{array}{l}\text { Sangat } \\
\text { baik }\end{array}$ & $85-100$ & 4 & 370 & $12 \%$ & \multirow{5}{*}{$\begin{array}{l}\text { 1. Rata-rata nilai yang diperoleh } \\
\text { peserta didik } 2203 / 32=68,84 \text { dan } \\
\text { termasuk dalam kategori baik } \\
\text { 2. Ketuntasan individu dengan skor } \\
\text { maksimal } 61 \text { dicapai oleh } 17 \text { peserta } \\
\text { didik } \\
\text { 3. Ketuntasan klasikal dengan rata- } \\
\text { rata } 1569 / 20=78,45 \text { atau } 62 \% \text { dari } \\
\text { total peserta didik yang ada. }\end{array}$} \\
\hline 2 & Baik & $61-84$ & 16 & 1186 & $50 \%$ & \\
\hline 3 & Cukup & $51-60$ & 8 & 447 & $25 \%$ & \\
\hline 4 & Kurang & $0-50$ & 4 & 200 & $13 \%$ & \\
\hline & Jumlah & & 32 & 2203 & & \\
\hline
\end{tabular}

Berdasarkan data pada Tabel 5 di atas ditunjukkan bahwa kemampuan menulis kalimat berhuruf jawa menggunakan pasangan peserta didik kelas VIC SD Negeri Landungsari 01 Kota
Pekalongan pada siklus I dalam kategori baik, terbukti dengan nilai rata-rata kelas yang dicapai sebesar 68,84 dalam rentang nilai 61-84. Berdasarkan data dari tabel tersebut, peserta didik yang mendapatkan 
nilai dengan kateori sangat baik ada 4 atau sebesar $12 \%$. Terdapat 16 peserta didik atau sebesar $50 \%$ yang mendapatkan nilai dengan kategori baik dengan jumlah skor 1186. Adapun kategori cukup sebanyak 8 peserta didik atau sebesar $25 \%$ dengan rentang nilai 51-60. Sebagian besar peserta didik memperoleh skor berkategori baik. Namun begitu masih perlu dilakukan perbaikan, agar kemampuan dalam menulis kalimat berhuruf jawa menggunakan pasangan peserta didik lebih meningkat. Berikut perincian hasil tes kemampuan dalam menulis kalimat berhuruf jawa menggunakan pasangan untuk setiap indikator pada siklus I.

\section{Respon Peserta didik selama Proses Pembelajaran Menulis Kalimat Berhuruf Jawa Menggunakan Pasangan}

\section{dengan model Pembelajaran Kooperatif tipe MAM}

Selama proses kegiatan pembelajaran menulis kalimat berhuruf jawa menggunakan pasangan dengan model pembelajaran kooperatif tipe MAM (Make A Match), tidak semua peserta didik mengikuti proses pembelajaran dengan baik. Peneliti dapat memaklumi keadaan tersebut karena proses pembelajaran yang dilakukan peneliti merupakan sesuatu yang baru dan belum pernah diajarkan pada peserta didik sebelumnya, sehingga dibutuhkan proses untuk menyesuaikannya. Pada pembelajaran sebelumnya masih sering dilakukan secara konvensional, yang terkesan kegiatannya monoton. Berikut adalah tabel data hasil observasi yang diperoleh peneliti.

Tabel 6. Hasil Observasi Perilaku Peserta Didik

\begin{tabular}{|c|c|c|c|c|}
\hline \multirow[b]{2}{*}{ Indikator } & \multicolumn{4}{|c|}{ Jumlah Peserta Didik } \\
\hline & Aktif & Presentase & $\begin{array}{l}\text { Tidak } \\
\text { Aktif }\end{array}$ & Presentase \\
\hline $\begin{array}{l}\text { 1. Respon peserta didik dalam } \\
\text { menerima materi }\end{array}$ & 25 & $78 \%$ & 7 & $22 \%$ \\
\hline $\begin{array}{l}\text { 2. Antusias dalam pembentukan } \\
\text { kelompok }\end{array}$ & 25 & $78 \%$ & 7 & $22 \%$ \\
\hline 3. Sikap menghargai pendapat teman & 23 & $72 \%$ & 9 & $28 \%$ \\
\hline 4. Keaktifan dalam membantu teman & 21 & $66 \%$ & 11 & $34 \%$ \\
\hline $\begin{array}{l}\text { 5. Kemampuan berkomunikasi dengan } \\
\text { teman }\end{array}$ & 23 & $72 \%$ & 9 & $28 \%$ \\
\hline 6. Keseriusan mengerjakan kuis & 24 & $75 \%$ & 8 & $25 \%$ \\
\hline 7. Ketepatan waktu mengerjakan tugas & 25 & $78 \%$ & 7 & $22 \%$ \\
\hline
\end{tabular}

Berdasarkan Tabel 6 tersebut dapat diketahui bahwa respon peserta didik dalam menerima materi yang aktif sebanyak 25 pestra didik atau $78 \%$, sedangkan sisanya 7 peserta didik atau $22 \%$ peserta didik yang tidak aktif. Untuk indikator antusias peserta didik dalam pembentukan kelompok yang aktif sebanyak 25 peserta didik atau $78 \%$, sedangkan sisanya sebesar 7 peserta didik atau 22\% tidak aktif. Untuk indikator sikap peserta didik dalam menghargai pendapat teman sebesar 23 atau $72 \%$, sedangkan peserta didik yang kurang menghargai pendapat teman sebesar 9 bpeserta didik atau $28 \%$. Untuk indikator keaktifan 
dalam membantu teman sebanyak 21 peserta didik aktif atau sebesar $66 \%$, sedangkan peserta didik yang tidak aktif sebanyak 11 peserta didik atau sebesar $28 \%$. Untuk indikator kemampuan berkomunikasi dengan teman sebanyak 23 peserta didik atau sebanyak $72 \%$, sedangkan peserta didik yang berkomunikasi dengan teman tetapi tidak aktif sebanyak 9 peserta didik atau sebesar 28\%. Untuk indikator keseriusan mengerjakan kuis peserta didik yang aktif sebanyak 24 peserta atau sebanyak $75 \%$ sedangkan peserta didik yang tidak aktif sebanyak 8 peserta didik atau sebesar $25 \%$. Untuk indikator ketepatan waktu mengerjakan tugas peserta didik yang tepat sebanyak 25 peserta atau sebanyak $78 \%$ sedangkan peserta didik yang kurang tepat sebanyak 7 peserta didik atau sebesar $22 \%$.

\section{Hasil siklus 2 \\ Proses Pembelajaran Menulis Kalimat Berhuruf Jawa Menggunakan Pasangan Dengan Model Pembelajaran Kooperatif tipe MAM}

Proses pembelajaran menulis kalimat berhuruf jawa menggunakan pasangandengan model pembelajaran kooperatif tipe MAM (Make A Match) pada siklus II hampir sama dengan proses pembelajaran siklus I dengan beberapa proses. Proses pembelajaran menulis kalimat berhuruf jawa menggunakan pasangandengan model pembelajaran kooperatif tipe MAM (Make A Match) yaitu sebagai berikut:

Tabel 7. Proses Pembelajaran

\begin{tabular}{|c|l|c|c|}
\hline No & \multicolumn{1}{|c|}{ Indikator } & F & Prosentase \\
\hline 1 & $\begin{array}{l}\text { Intensifnya proses internalisasi penumbuhan minat } \\
\text { pada pembelajaran Bahasa Jawa. }\end{array}$ & 29 & $91 \%$ \\
\hline 2 & $\begin{array}{l}\text { Terjadinya proses penjelasan yang kondusif tentang cara } \\
\text { menulis kalimat berhuruf Jawa menggunakan pasangan.. }\end{array}$ & 26 & $81 \%$ \\
\hline 3 & $\begin{array}{l}\text { Intensifnya proses peserta didik berdiskusi dengan } \\
\text { didampingi guru sehingga peserta didik mampu } \\
\text { berperilaku melestarikan budaya Jawa. }\end{array}$ & 28 & $88 \%$ \\
\hline 4 & $\begin{array}{l}\text { Kondusifnya kondisi peserta didik saat memaparkan } \\
\text { hasil diskusi di depan kelas }\end{array}$ & 25 & $78 \%$ \\
\hline 5 & $\begin{array}{l}\text { Terbangunnya suasana yang reflektif sehingga peserta } \\
\text { didik bisa menyadari kekurangan saat proses } \\
\text { pembelajaran dan mengetahui apa yang akan dilakukan } \\
\text { setelah proses pembelajaran. }\end{array}$ & 27 & $84 \%$ \\
\hline
\end{tabular}

Dari tabel 7 di atas ditunjukkan indikator intensifnya proses intensifnya proses internalisasi penumbuhan minat pada pembelajaran menulis kalimat berhuruf jawa menggunakan pasangan, terdapat 29 peserta didik yang memperhatikan atau sebesar $91 \%$ dan termasuk dalam kategori sangat baik, hal ini mengalami peningkatan dari proses pembelajaran indikator ini yang pada siklus I yang hanya 23 peserta didik atau sebesar $72 \%$. Indikator terjadinya proses penjelasan yang kondusif tentang cara menulis kalimat berhuruf Jawa menggunakan pasangan, terdapat 26 peserta didik yang memperhatikan atau sebesar $81 \%$ dan termasuk dalam kategori sangat baik, hal ini mengalami peningkatan dari proses pembelajaran indikator ini pada siklus I yang hanya 21 peserta didik atau sebesar $67 \%$. Indikator intensifnya proses peserta didik berdiskusi dengan didampingi guru sehingga peserta didik mampu berperilaku melestarikan budaya jawa ,terdapat 28 peserta didik yang intensif berdiskusi atau sebesar $88 \%$ dan 
termasuk dalam kategori sangat baik, hal ini mengalami peningkatan dari proses pembelajaran indikator ini pada siklus I yang hanya 22 peserta didik atau sebesar $69 \%$. Indikator kondusifnya kondisi peserta didik saat memaparkan hasil diskusi di depan kelas,terdapat 25 peserta didik yang kondisinya kondusif atau sebesar $78 \%$ dan termasuk dalam kategori baik, hal ini mengalami peningkatan dari proses pembelajaran indikator ini pada siklus I yang hanya 21 peserta didik atau sebesar $67 \%$.

Indikator terbangunnya suasana yang reflektif sehingga peserta didik bisa menyadari kekurangan saat proses pembelajaran dan mengetahui apa yang akan dilakukan setelah proses pembelajaran, terdapat 27 peserta didik yang menyadari atau sebesar $84 \%$ dan termasuk dalam kategori baik, hal ini mengalami peningkatan pada proses pembelajaran indikator ini pada siklus I yang hanya 20 peserta didik atau sebesar $63 \%$.

\section{Peningkatan Kemampuan Menulis Kalimat Berhuruf Jawa Menggunakan Pasangan Dengan Model Pembelajaran Kooperatif Tipe MAM}

Berdasarkan hasil tes pada siklus II, telah terjadi peningkatan kemampuan menulis kalimat berhuruf jawa menggunakan pasanganpada peserta didik kelas VIC SD Negeri Landungsari 01 Kota Pekalongan. Peningkatan ini dipengaruhi oleh penggunaan model pembelajaran kooperatif tipe MAM (Make A Match) dalam pembelajaran. Untuk lebih jelasnya dapat dilihat pada tabel di bawah ini.

Tabel 8. Hasil Tes Kemampuan Menulis Kalimat Berhuruf Jawa Menggunakan Pasangan Pada Siklus II

\begin{tabular}{|l|l|c|c|c|c|c|}
\hline No & Kategori & $\begin{array}{c}\text { Rentang } \\
\text { Nilai }\end{array}$ & F & Bobot & $\begin{array}{c}\text { Presen } \\
\text { tase }\end{array}$ & \multicolumn{1}{|c|}{ Rata-rata } \\
\hline 1 & $\begin{array}{l}\text { Sangat } \\
\text { Baik }\end{array}$ & $85-100$ & 9 & 828 & $28 \%$ & 1. $\begin{array}{l}\text { Rata-rata nilai yang diperoleh peserta } \\
\text { didik 2532/32=79,13 termasuk dalam } \\
\text { kategori baik }\end{array}$ \\
\hline 2 & Baik & $61-84$ & 21 & 1584 & $66 \%$ & 2. $\begin{array}{l}\text { Ketuntasan individu dengan skor } \\
\text { maksimal 61 dicapai 30 peserta didik } \\
\text { Ketuntasan klasikal dengan rata-rata } \\
\text { 2412/30=80,4 atau 94\% dari total } \\
\text { peserta didik yang ada. }\end{array}$ \\
\hline 4 & Kukup & $51-60$ & 2 & 120 & $6 \%$ \\
\hline
\end{tabular}

Berdasarkan data pada Tabel 8 di atas ditunjukkan bahwa kemampuan menulis kalimat berhuruf jawa menggunakan pasangan peserta didik kelas VIC SD Negeri Landungsari 01 Kota Pekalongan pada siklus II dalam kategori baik, terbukti dengan nilai rata-rata kelas yang dicapai sebesar 77,6 dalam rentang nilai 61-84. Berdasarkan data dari tabel tersebut, peserta didik yang mendapatkan nilai dengan kateori sangat baik ada 7 . Terdapat 22 peserta didik atau sebesar 69 $\%$ yang mendapatkan nilai dengan kategori baik dengan jumlah skor 1649. Berikut perincian hasil tes kemampuan dalam menulis kalimat berhuruf jawa menggunakan pasangan untuk setiap indikator pada siklus II.

Perilaku Peserta didik setelah Pembelajaran Menulis Kalimat Berhuruf Jawa Menggunakan Pasangan dengan Model Pembelajaran Kooperatif Tipe MAM

Hasil perilaku peserta didik setelah mengikuti pembelajaran menulis kalimat berhuruf jawa menggunakan pasangan dengan model pembelajaran kooperatif tipe MAM (Make A Match) pada peserta didik kelas VIC SD Negeri Landungsari 01 Kota Pekalongan pada siklus II terdapat tujuh 
karakter peserta didik yang dijelaskan pada tabel berikut.

Tabel 9

Hasil Observasi Perilaku Peserta didik setelah Mengikuti Pembelajaran Siklus II

\begin{tabular}{|l|c|c|c|c|}
\hline \multirow{2}{*}{ Indikator } & \multicolumn{4}{|c|}{ Jumlah Peserta Didik } \\
\cline { 2 - 5 } & Aktif & Presentase & $\begin{array}{c}\text { Tidak } \\
\text { Aktif }\end{array}$ & Presentase \\
\hline $\begin{array}{l}\text { 1. } \\
\text { Respon peserta didik dalam menerima } \\
\text { materi }\end{array}$ & 29 & $91 \%$ & 3 & $9 \%$ \\
\hline 2. Antusias dalam pembentukan kelompok & 27 & $84 \%$ & 5 & $16 \%$ \\
\hline 3. Sikap menghargai pendapat teman & 29 & $91 \%$ & 3 & $9 \%$ \\
\hline 4. Keaktifan dalam membantu teman & 26 & $81 \%$ & 6 & $19 \%$ \\
\hline 5. Kemampuan berkomunikasi dengan teman & 27 & $84 \%$ & 5 & $16 \%$ \\
\hline 6. Keseriusan mengerjakan kuis & 29 & $91 \%$ & 3 & $9 \%$ \\
\hline 7. Ketepatan waktu mengerjakan tugas & 28 & $87 \%$ & 4 & $13 \%$ \\
\hline
\end{tabular}

Berdasarkan Tabel 9 tersebut dapat diketahui bahwa respon peserta didik dalam menerima materi yang aktif sebanyak 29 peserta didik atau sebesar $91 \%$, sedangkan sisanya sebanyak 3 peserta didik atau sebesar $9 \%$ peserta didik yang tidak aktif. Untuk indikator antusias peserta didik dalam pembentukan kelompok yang aktif sebanyak 27 peserta didik atau $84 \%$, sedangkan sisanya sebesar 5 peserta didik atau $16 \%$ tidak aktif. Untuk indikator sikap peserta didik dalam menghargai pendapat teman sebesar 29 atau $91 \%$, sedangkan peserta didik yang kurang menghargai pendapat teman sebesar 3 peserta didik atau 9\%. Untuk indikator keaktifan dalam membantu teman sebanyak 26 peserta didik aktif atau sebesar $81 \%$, sedangkan peserta didik yang tidak aktif sebanyak 6 peserta didik atau sebesar 19\%. Untuk indikator kemampuan berkomunikasi dengan teman sebanyak 27 peserta didik atau sebanyak $84 \%$, sedangkan peserta didik yang berkomunikasi dengan teman tetapi tidak aktif sebanyak 5 peserta didik atau sebesar $16 \%$. Untuk indikator keseriusan mengerjakan kuis peserta didik yang aktif sebanyak 29 peserta atau sebanyak $91 \%$ sedangkan peserta didik yang tidak aktif sebanyak 3 peserta didik atau sebesar $9 \%$.
Untuk indikator ketepatan waktu mengerjakan tugas peserta didik yang tepat sebanyak 28 peserta atau sebanyak $87 \%$ sedangkan peserta didik yang kurang tepat sebanyak 4 peserta didik atau sebesar $13 \%$.

\section{Pembahasan}

\section{Proses Pembelajaran Menulis Kalimat Berhuruf Jawa Menggunakan Pasangan dengan Model Pembelajaran Kooperatif Tipe MAM}

Proses kegiatan pembelajaran menulis kalimat berhuruf jawa menggunakan pasangandengan model pembelajaran kooperatif tipe MAM (Make A Match) pada siklus I dilakukan dua kali pertemuan dan pada siklus II hanya dilakukan satu kali pertemuan. Setiap pertemuan selalu diawali dengan mengkondisikan peserta didik agar siap mengikuti pembelajaran sehingga tercipta suasana yang kondusif dan komunikatif, setelah itu guru menyampaikan kemampuan yang akan dipelajari. Selanjutnya guru melakukan apersepsi yaitu mencoba memberikan pertanyaan kepada peserta didik yang berkaitan dengan pembelajaran menulis kalimat berhuruf jawa menggunakan pasangan, sehingga peserta didik selalu terlatih untuk 
berpikir. Selanjutnya guru (peneliti) menjelaskan segala kegiatan yang akan dilakukan peserta didik dan peserta didik melakukan tanya jawab dengan guru mengenai kegiatan pembelajaran menulis kalimat berhuruf jawa menggunakan pasangan

Memasuki kegiatan inti, peserta didik memperhatikan penjelasan dari guru tentang materi yang akan dibahas, yaitu menulis kalimat berhuruf jawa menggunakan pasangan. Peserta didik diajak untuk latihan menulis huruf jawa dan pasangan huruf jawa sebagai bahan diskusi dengan teman sekelompoknya. Pada pertemuan pertama siklus I ini Guru mempersiapkan kartu huruf jawa, pasangan huruf jawa, beberapa kalimat dengan huruf jawa dan peserta didik memperhatikan demontrasi pelaksanaan model pembelajaran MAM (Make A Match).Selanjutnya peserta didik melakukan kegiatan didampingi oleh guru.membentuk kelompok yang beranggotakan 4-5 peserta didik. Setelah membentuk kelompok, guru membagikan lembar kerja dan menjelaskan kegiatan yang harus dilakukan setiap anggota kelompok.Selanjutnya peserta didik berdiskusi dengan teman sekelompok untuk menemukan jawaban dari lembar kerja yang dibagikan guru. Hasil diskusi tiap kelompok disimpan terlebih dahulu sebelum dibahas dalam diskusi kelas.

Pada siklus I pertemuan kedua, perwakilan kelompok maju secara bergiliran untuk mempresentasikan hasil diskusi. Sementara itu, kelompok lain memperhatikan dan memberi tanggapan terhadap hasil diskusi dari kelompok yang maju. Hasil pekerjaan peserta didik dikumpulkan pada guru dan kemudian hasil tersebut dinilai guru untuk mengetahui hasil diskusi kelompok kalimat berhuruf jawa menggunakan pasangan yang telah dilakukan peserta didik.

Kegiatan pada siklus II hanya memperjelas dan perbaikan pada indikator kemampuan menulis kalimat berhuruf jawa menggunakan pasangan dan mengulas kembali penjelasan yang telah diberikan guru pada siklus I. Siklus II dilakukan satu pertemuan (2 jam pelajaran). Sebagian besar peserta didik berperan aktif menulis kalimat berhuruf jawa menggunakan pasangan. Pada siklus II peserta didikmelaksanakan pembelajaran model kooperatif tipe MAM (Make A Match) secara langsung melaksanakan dengan petunjuk dari guru. Guru memberikan aba untuk peserta didik mencari pasangan setelah mendapatkan kartu. Kegiatan mencari pasangan dilakukan beberapa kali dengan kartu yang berbeda. Peserta didik juga diharuskan membentuk kelompok. Namun, pada siklus II ini pembentukan kelompok ditentukan oleh guru yakni tiap kelompok akan diketuai oleh peserta didik yang mendapat nilai tertinggi pada siklus I. Hal ini ditujukan agar ditiap kelompoknya nanti ada yang memimpin diskusi dan anggota kelompok yang belum paham materi dapat bertanya pada ketua kelompoknya.

Pada tahap penutup siklus I dan siklus II adalah sama, yaitu mengadakan refleksi dan simpulan untuk kegiatan pembelajaran pada hari itu, memberikan manfaat yang diperoleh, dan memberikan motivasi peserta didik agar mau terus belajar. Kesimpulan yang dibuat peserta didik sebagai pengukur kemampuan menulis kalimat berhuruf jawa menggunakan pasangan. Kemudian dilanjutkan dengan mengisi lembar catatan harian yang telah disiapkan peneliti.

Tabel 10 Proses Pembelajaran Siklus I dan Siklus II

\begin{tabular}{|l|l|c|c|c|c|}
\hline \multirow{2}{*}{ No } & \multicolumn{1}{|c|}{ Indikator } & \multicolumn{2}{|c|}{ F } & \multicolumn{2}{c|}{$\begin{array}{c}\text { Prosentase } \\
(\%)\end{array}$} \\
\cline { 3 - 6 } & \multicolumn{1}{|c|}{ SI } & SII & SI & SII \\
\hline 1. & $\begin{array}{l}\text { Intensifnya proses internalisasi penumbuhan minat pada } \\
\text { pembelajaran menulis kalimat berhuruf jawa menggunakan } \\
\text { pasangan }\end{array}$ & 23 & 29 & $72 \%$ & $91 \%$ \\
\hline
\end{tabular}




\begin{tabular}{|l|l|l|l|l|l|}
\hline 2. & $\begin{array}{l}\text { Terjadinya proses penjelasan yang kondusif tentang cara } \\
\text { menulis kalimat berhuruf jawa menggunakan pasangan. }\end{array}$ & 21 & 26 & $67 \%$ & $81 \%$ \\
\hline 3. & $\begin{array}{l}\text { Intensifnya proses peserta didik berdiskusi dengan } \\
\text { didampingi guru sehingga peserta didik mampu berperilaku } \\
\text { melestarikan budaya Jawa. }\end{array}$ & 22 & 28 & $69 \%$ & $88 \%$ \\
\hline 4. & $\begin{array}{l}\text { Kondusifnya kondisi peserta didik saat memaparkan hasil } \\
\text { diskusi di depan kelas }\end{array}$ & 21 & 25 & $67 \%$ & $78 \%$ \\
\hline 5. & $\begin{array}{l}\text { Terbangunnya suasana yang reflektif sehingga peserta didik } \\
\text { bisa menyadari kekurangan saat proses pembelajaran dan } \\
\text { mengetahui apa yang akan dilakukan setelah proses } \\
\text { pembelajaran. }\end{array}$ & 20 & $63 \%$ & $84 \%$ \\
\hline
\end{tabular}

$\begin{array}{ll}\text { Keterangan : } & \\ \text { Sangat baik } & : 85 \%-100 \% \\ \text { Baik } & : 61 \%-84 \% \\ \text { Cukup } & : 51 \%-60 \% \\ \text { Kurang } & : 0 \%-50 \%\end{array}$

\section{Peningkatan Kemampuan Menulis Klaimat Berhuruf Jawa Menggunakan Pasangan dengan Model Pembelajaran Kooperatif Tipe MAM}

Hasil tes kemampuan menulis kalimat berhuruf jawa menggunakan pasangan tersebut dapat dilihat pada tabel berikut ini:

Tabel 11 Peningkatan Hasil Tes Kemampuan Menulis Klaimat Berhuruf Jawa Menggunakan Pasangan pada Siklus I dan Siklus II

\begin{tabular}{|c|c|c|c|c|c|c|c|c|}
\hline \multirow[b]{2}{*}{ No } & \multirow{2}{*}{ Indikator } & \multicolumn{3}{|c|}{ Rata-rata } & Peningkatan & \multicolumn{3}{|c|}{ Ketuntasan } \\
\hline & & Pra & SI & SII & Pra - SI - SII & Pra & SI & SII \\
\hline \multirow[t]{2}{*}{1.} & & & & & & & & \\
\hline & $\begin{array}{l}\text { Menentukan pasangan huruf } \\
\text { jawa dalam kalimat }\end{array}$ & 59,38 & 81,56 & 82,50 & $22,18-0,94$ & $31 \%$ & $81 \%$ & $91 \%$ \\
\hline 2. & $\begin{array}{l}\text { Menulis kalimat berhuruf } \\
\text { jawa menggunakan pasangan }\end{array}$ & 50,94 & 59,40 & 71,90 & $8,46-12,50$ & $16 \%$ & $41 \%$ & $84 \%$ \\
\hline \multirow[t]{2}{*}{3.} & $\begin{array}{l}\text { Menyalin kalimat tulisan } \\
\text { huruf jawa dengan tulisan } \\
\text { huruf latin }\end{array}$ & 54,69 & 65,30 & 80,9 & $10,61-15,60$ & $19 \%$ & $53 \%$ & $91 \%$ \\
\hline & & 55,16 & 68,84 & 78,80 & $13,68-9,96$ & $22 \%$ & $\begin{array}{c}58,3 \\
\%\end{array}$ & $\begin{array}{c}88,7 \\
\%\end{array}$ \\
\hline
\end{tabular}

Berdasarkan Tabel 11 dapat diketahui bahwa kemampuan peserta didik pada setiap indikator penilaian menulis kalimat berhuruf jawa menggunakan pasanganmengalami peningkatan rata-rata yang dicapai peserta didik. Pada kegiatan pra siklus pembelajaran menulis kalimat berhuruf jawa menggunakan pasangannilairata-rataadalah 55,16. Pada siklus I pembelajaran menulis kalimat berhuruf jawa menggunakan pasangan nilairata-rataadalah 68,84 . Sedangkan pada siklus II peserta didik memperoleh nilai rata-rata 78,80. Hal tersebut menunjukkan bahwa nilai peserta didik mengalami peningkatan dari kegiatan prasiklus ke siklus I adalah 13,75 dan siklus II sebesar 9,68. Yang mencapai KKM pada kegiatan prasiklus hanya 22\%. Setelah menggunakan model kooperatif tipe MAM 
(Make A Match) pada siklus I maka peserta didik yang mendapat nilai di atas KKM adalah 58\% sedangakan pada siklus II meningkat menjadi 88,7\%.

Peningkatan kemampuan peserta didik dalam menulis kalimat berhuruf jawa menggunakan pasanganditunjukkan dengan meningkatnya rata-rata skor pada setiap indikator penilaian. Indikator penilaian tes menulis kalimat berhuruf jawa menggunakan pasangantersebut terdiri atas tiga indikator, yaitu indikator (1) mampu menentukan pasangan huruf jawa dalam kalimat. 2) mampu menulis kalimat berhuruf jawa menggunakan pasangan (3) mampu menyalin kalimat tulisan huruf jawa dengan tulisan huruf latin

Pada siklus I rata-rata skor indikator mampu menentukan pasangan huruf jawa dalam kalimat adalah 81,56. Hasil indikator menentukan pasangan huruf jawa dalam kalimat pada siklus II adalah 82,50 dan mengalami peningkatan sebesar 0,98. Indikator mampu menulis kalimat berhuruf jawa menggunakan pasangan mengalami peningkatan sebesar 12,50 dibandingkan pada siklus I. Rata-rata siklus I sebesar 59,40 menjadi 71,90. Hal ini dikarenakan peserta didik telah belajar dari kesalahan yang terjadi pada pembelajaran-pembelajaran sebelumnya. Pada siklus I nilai rata-rata skor indikator mampu menyalin kalimat tulisan huruf jawa dengan tulisan huruf latinyang diperoleh adalah 65,30 dan mengalami peningkatan pada siklus II menjadi 80,9.

Peningkatan kemampuan menulis kalimat berhuruf jawa menggunakan pasanganmerupakan suatu keberhasilan yang membanggakan. Setelah dilakukan tindakan dengan menggunakan model pembelajaran kooperatif tipe MAM (Make A Match) pada siklus I, kemampuan menulis kalimat berhuruf jawa menggunakan pasangan,peserta didik yang masih mencapai kategori cukup dapat diperbaiki pada siklus II. Dengan demikian dapat disimpulkan bahwa model pembelajaran kooperatif tipe MAM (Make A Match) membantu peserta didik dalam pembelajaran menulis kalimat berhuruf jawa menggunakan pasangan.

\section{Perubahan Perilaku Belajar Peserta Didik setelah Mengikuti Pembelajaran Menulis Kalimat Berhuruf Jaw Menggunakan Pasangan dengan Model Pembelajaran Kooperatif Tipe MAM}

Penelitian yang dilakukan oleh peneliti tidak hanya meneliti kompetensi menulis Kalimat berhuruf jawa menggunakan pasangan saja, tetapi juga meneliti perubahan perilaku peserta didik pada siklus I dan siklus II.

Pada penelitian ini, perubahan perilaku dialami peserta didik setelah mengikuti pembelajaran menulis kalimat berhuruf jawa menggunakan pasangandengan model pembelajaran kooperatif tipe MAM (Make A Match) siklus I dan siklus II. Hal ini merupakan implementasi dari nilai-nilai pendidikan karakter saat proses pembelajaran. Nilainilai tersebut meliputi Respon peserta didik dalam menerima materi, dan aktivitas peserta didik, Antusias dalam pembentukan kelompok, Keaktifan dalam membantu teman, Kemampuan berkomunikasi dengan teman, Keseriusan mengerjakan kuis, Ketepatan waktu mengerjakan tugas serta membuat catatan. Peserta didik selalu menunjukkan perubahan perilaku positif dengan sikap menghargai pendapat teman saat proses pembelajaran berlangsung.

Perubahan perilaku peserta didik
yang diharapkan selama proses
pembelajaran tersebut terdapat tujuh
karekter peserta didik yang dijelaskan pada
tabel berikut.

Tabel 12 Perilaku Peserta didik setelah Mengikuti Pembelajaran Siklus I dan Siklus II 


\begin{tabular}{|ll|c|c|c|c|}
\hline & Aktif & Tdk & Aktif & Tdk \\
\hline 1. & Respon peserta didik dalam menerima materi & $78 \%$ & $22 \%$ & $91 \%$ & $9 \%$ \\
\hline 2. & Antusias dalam pembentukan kelompok & $78 \%$ & $22 \%$ & $84 \%$ & $16 \%$ \\
\hline 3. & Sikap menghargai pendapat teman & $72 \%$ & $28 \%$ & $91 \%$ & $9 \%$ \\
\hline 4. & Keaktifan dalam membantu teman & $69 \%$ & $31 \%$ & $81 \%$ & $19 \%$ \\
\hline 5. & Kemampuan berkomunikasi dengan teman & $72 \%$ & $28 \%$ & $84 \%$ & $16 \%$ \\
\hline 6. & Keseriusan mengerjakan kuis & $75 \%$ & $25 \%$ & $91 \%$ & $9 \%$ \\
\hline 7. & Ketepatan waktu mengerjakan tugas & $78 \%$ & $22 \%$ & $87 \%$ & $13 \%$ \\
\hline
\end{tabular}

Berdasarkan Tabel 12 di atas dapat diketahui bahwa perilaku peserta didik setelah mengikuti pembelajaran pada setiap indikator mengalami peningkatan. Untuk indikator Respon peserta didik dalam menerima materi pada siklus I sebesar $78 \%$ sedangkan pada siklus II sebesar $91 \%$, indikator ini mengalami peningkatan sebesar $41 \%$. Untuk indikator Antusias dalam pembentukan kelompok pada siklus I sebesar $78 \%$ sedangkan pada siklus II sebesar 84\%, indikator ini mengalami peningkatan sebesar $6 \%$. Untuk indikator Sikap menghargai pendapat teman padasiklus I sebesar $72 \%$ sedangkan pada siklus II sebesar 91\%, indikator ini mengalami peningkatan sebesar 19\%. Untuk indikator Keaktifan dalam membantu teman pada siklus I sebesar $69 \%$ sedangkan pada siklus II sebesar $81 \%$, indikator ini mengalami peningkatan sebesar $12 \%$. Untuk indikator Kemampuan berkomunikasi dengan teman pada siklus I sebesar $72 \%$ sedangkan pada siklus II sebesar $84 \%$, indikator ini mengalami peningkatan sebesar $12 \%$. Untuk keseriusan mengerjakan mengerjakan kuis pada siklus I sebesar $75 \%$ sedangkan pada siklus II sebesar $91 \%$, indikator ini mengalami peningkatan sebesar $16 \%$. Untuk indikator Ketepatan waktu mengerjakan tugas pada siklus I sebesar $78 \%$ sedangkan pada siklus II sebesar $87 \%$, indikator ini mengalami peningkatan sebesar $9 \%$.

\section{PENUTUP \\ Simpulan}

Simpulan hasil penelitian ini: 1) Proses pembelajaran menulis kalimat berhuruf jawa menggunakan pasangan dengan model pembelajaran kooperatif tipe MAM (Make A Match) pada siklus I dan siklus II mengalami peningkatan ke arah positif. Hal ini terlihat dari adanya peningkatan di setiap aspek proses pembelajaran menulis kalimat berhuruf jawa menggunakan pasangan. Dengan demikian, dapat dikatakan bahwa proses pembelajaran menulis kalimat berhuruf jawa menggunakan pasangan dengan model pembelajaran kooperatif tipe MAM (Make A Match) pada siklus II sudah berjalan dengan baik. 2) Kemampuan menulis kalimat berhuruf jawa menggunakan pasangan dengan model pembelajaran kooperatif tipe MAM (Make A Match) pada peserta didik kelas VIC SD Negeri Landungsari 01 Kota Pekalongan mengalami peningkatan. Nilai rata-rata yang dicapai peserta didik pada prasiklus sebesar 55,16 dan berada dalam kategori cukup. Pada siklus I, nilai ratarata peserta didik mengalami peningkatan sebesar 13,68 atau sebesar $43 \%$ menjadi sebesar 68,84 dan berada dalam kategori baik. Nilai rata-rata pada siklus I sudah mencapai batas ketuntasan yang telah ditetapkan oleh peneliti tetapi tetap dilakukan siklus II untuk pemantapan hasilnya. Setelah dilaksanakan tindakan siklus II, nilai rata-rata peserta didik mengalami peningkatan sebesar 9,96 atau sebesar $31 \%$ menjadi sebesar 78,80 dan berada dalam kategori baik. Peningkatan nilai rata-rata tersebut membuktikan keberhasilan pembelajaran menulis kalimat berhuruf jawa menggunakan pasangan dengan model pembelajaran kooperatif 
tipe MAM (Make A Match). 3) Perilaku peserta didik kelas VIC SD Negeri Landungsari 01 Kota Pekalongan setelah melaksanakan pembelajaran menulis kalimat berhuruf jawa menggunakan pasangan dengan model pembelajaran kooperatif tipe MAM (Make A Match) mengalami perubahan ke arah positif. Perubahan peserta didik mencakup tujuh karakter penting yaitu, respon peserta didik dalam menerima materi, antusias dalam pembentukan kelompok, sikap menghargai teman, keaktifan dalam membantu teman, kemampuan berkominikasi dengan teman, keseriusan mengerjakan kuis dan ketepatan dalam mengerjakan tugas.

\section{Saran}

Berdasarkan simpulan penelitian tersebut, maka saran yang diberikan olehpeneliti adalah sebagai berikut: 1) Guru mata pelajaran Bahasa Jawa dapat memanfaatkan model pembelajaran kooperatif tipe MAM (Make A Match) sebagai salah satu alternatif dalam pembelajaran, karena terbukti dapat meningkatkan kemampuan peserta didik menulis kalimat berhuruf jawa menggunakan pasangan. Selain itu, guru Bahasa Jawa hendaknya mengetahui perkembangan zaman agar dapat memberikan inovasi dalam pembelajaran sehingga pembelajaran tidak membosankan dan juga untuk mempersiapkan peserta didik pada kelas berikutnya; 2) Para peneliti yang menekuni bidang penelitian Bahasa Jawa kiranya dapat melakukan penelitian lanjutan mengenai pembelajaran menulis kalimat berhuruf jawa menggunakan pasangan dengan model pembelajaran kooperatif tipe MAM (Make A Match) .Para peneliti dapat menerapkan berbagai strategi, model, metode, teknik, dan media berdasarkan pendekatan tertentu yang tepat untuk meningkatkan kemampuan peserta didik dalam menulis kalimat berhuruf jawa menggunakan pasangan. Hasil penelitian tersebut diharapkan dapat membantu guru untuk memecahkan masalah yang sering muncul dalam proses pembelajaran Bahasa Jawa di kelas.

\section{DAFTAR PUSTAKA}

Oemar Hamalik. (1994:7). Kurikulum dan Pembelajaran. Jakarta: Sinar Grafika

Abdul Majid dan Dian Andayani, (2004 :51-52), Pendidikan Agama Islam BerbasisKemampuan,Konsep Dan ImplementasiKurikulum, Bandung : PT RemajaRosda Karya.

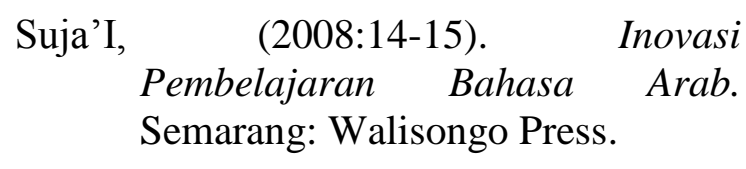

Sumiati,Asra, (2009:245-246).Metode Pembelajaran. Bandung: CV Wacana Prima

Undang-Undang RI nomor 20 tahun 2003 tentang Sistem Pendidikan Nasional

Rusman.(2011:223-233). Model-model Pembelajaran Mengembangkan Profesional Guru. Jakarta: Rajawali Press 